\title{
Family Interaction and Emotional Intelligence of School-Age Children in Urban Poor Areas
}

\author{
Inten Rengganis Sukmawati* \\ Department of Family and Consumer Sciences, Department of Family and Consumer Sciences, \\ Faculty of Human Ecology, Faculty of Human Ecology, \\ Bogor Agricultutal University Bogor Agricultutal University \\ *Corresponding author: inten.rengganis@ yahoo.co.id
}

\begin{abstract}
Emotional intelligence is the ability of children to express their emotions appropriately. Emotions play an important role in children's lives because through the emotion someone knows what was perceived themselves and others. The aim of this research was to analyze the influence of the characteristics of children and family, interaction between children and parents as well as siblings toward school-age children's emotional intelligence. The study design was cross-sectional study with proportional random sampling method. Samples in this study were children and mothers $(n=100)$ in urban poor areas, which are located in Empang Village and Tegal Lega Village, Bogor City. Data were collected by interview using a questionnaire. The results showed that there is a negative significant relation between age of mother and parentchild interaction. Mother's education length and sibling interaction have a positive significant relation with emotional intelligence. Emotional intelligence of school-age children in urban poor areas was affected by mother's education length and sibling interaction. Age of child does not influence on child emotional intelligence in urban poor areas.
\end{abstract}

Keywords: emotional intelligence, parent-child interaction, school-age children, sibling interaction, urban poor areas

Kecerdasan emosional merupakan kemampuan anak dalam mengekspresikan emosinya dengan tepat. Emosi berperan penting dalam kehidupan anak karena melalui emosi seseorang mengetahui apa yang dirasakan dirinya dan orang lain. Penelitian ini bertujuan untuk menganalisis pengaruh karakteristik anak dan keluarga, interaksi anak dengan orang tua serta saudara kandung terhadap kecerdasan emosional anak usia sekolah. Desain penelitian ini menggunakan cross-sectional study dengan metode proportional random sampling. Contoh dalam penelitian ini yaitu 100 anak dan ibu di wilayah miskin perkotaan yaitu di Kelurahan Empang dan Kelurahan Tegal Lega, Kota Bogor. Data dikumpulkan dengan wawancara menggunakan kuesioner. Hasil penelitian menunjukkan bahwa terdapat hubungan negatif signifikan antara usia ibu dengan interaksi orang tua dan anak. Lama pendidikan ibu dan interaksi saudara kandung berhubungan positif signifikan dengan kecerdasan emosional. Kecerdasan emosional anak usia sekolah di wilayah miskin perkotaan dipengaruhi oleh lama pendidikan ibu dan interaksi saudara kandung. Usia anak tidak berpengaruh terhadap kecerdasan emosional anak.

Kata kunci: anak usia sekolah, kecerdasan emosional, interaksi orang tua-anak, interaksi saudara kandung, wilayah miskin perkotaan 


\section{Introduction}

Poverty is a social phenomenon that happens all the time. One of the areas that has poverty problems in West Java is the city of Bogor. According to the Central Bureau of Statistics (BPS) in 2015 Bogor City has a poverty rate which ranks the third with a poor population of 83.3 thousand inhabitants with a percentage of 8.19 percent. Poverty experienced by a family can be described by the level of family welfare. Poverty indicators from BKKBN were used to see the welfare of a family. BKKBN made five categories of family welfare namely Pre-Prosperous Family (Pre-S), Prosperous Family I (KS-I), Prosperous Family II (KS-II), Prosperous Family III (KSIII), and Prosperous Family III Plus (KS- III Plus).

Regardless of the economic well-being of a family, there is an important task to be fulfilled by parents for the child, that is, to help and facilitate each stage of child development, such as the development of emotions. Aber et al. (1997) says that poverty affects the cognitive, social and emotional development of children. According to Eamon (2001) poverty has an impact on child development. For example, children living in families with poverty have a higher risk of experiencing emotional social development problems.

According to Evans (2004), poor children experience lack of social support and have less responsive and more authoritarian parents. Children who have low incomes relatively rarely read books, and they more likely watch television and have less access to books and computers. Those who have low incomes are less involved with children's school activities. Water and air sources around children are polluted - noisy and low quality. A more dangerous environment offers services in urban poor and suffers greater physical damage. Low-income families do not pay attention to children's schools. This is an aspect that affects child poverty.

Low family economic conditions also tend to cause poor parental responsibilities to children (Warren et al. 2001 in Alfiasari 2007). This condition makes the parents are not too concerned about the process of development of their children. This is due to the busyness of parents in earning income to meet the needs of families. Children raised in low income families are at risk of problems in academic and social terms and poor health and well-being.

School-age children or so-called middle childhood aged in the range of 8-12 years (Gottman \& DeClaire 1997). These stages require the child to have the skills or competencies by viewing himself whether they are capable of mastering the various skills and able to complete the task. The initiative of the child brings them in touch with many new experiences. Children begin to interact with the environment outside the home like the school environment and peers.

The family is the child's first place to interact before the child interacts with the outside world. According to Hastuti et al. (2008), the situation in the family will directly and indirectly shapes the quality of interaction that occurs between mother and child. Activities conducted jointly between parents and children are part of the parent and child interaction (Irzalinda, Puspitawati \& Muflikhati 2014). According to Setyowati (2005) the implementation of communication made by the family as a form of interaction between parents with children and other family members has implications for the child's emotional development process. According to Gerard, there are seven dimensions measured in parent-child interaction: parental support, satisfaction, 
involvement, communication, boundary setting, autonomy, and value orientation. Family is the first school for emotional learning (Gottman \& DeClaire 1997).

In addition to interacting with his parents, children also interact with siblings. King (2007) says that the relationship among siblings is one of the important aspects in a family system, where you can be the first friend of a child and have a lifelong relationship. According to Furman and Buhrmester (1985) there are 4 dimensions that measure the relationship among siblings, which consist of warmth / closeness, status or power (relative power / status), conflict, and competition (rivalry ). Ali and Sarullah (2010) say that parents have a role in sharing information with children. Sharing information in this case is important because to understand each other and support his siblings, especially brothers with special needs.

Emotional intelligence is emotion-related intelligence and emotion-controlling skills that provide the ability to balance emotions so as to maximize interaction well. Goleman (2004) says that emotional intelligence is the capabilities encompassed in terms of self-control, passion and perseverance, As well as the ability to self-motivate.

According to Goleman (2004) the problems often occur in childhood in which children are naughty or aggressive. Children who have unstable emotional conditions usually involve in the behavior of mischief. Hoeve et al. (2009) says that there is a significant relationship between the nurture and delinquency dimensions but the magnitude of the relationship depends on the nurture dimension itself. Based on these descriptions, it is important to conduct research regarding the good interaction in the family towards the emotional intelligence of school-aged children in urban poor areas. The study was conducted with the aims of: 1) analyzing the characteristics of the family, characteristics of children, parent and child interactions, sibling interaction, and emotional intelligence, 2) analyzing the relationship between family and child characteristics, parent and child interaction, sibling and intelligence interaction Emotional children, 3) analyzing the effect of characteristics, parent-child interactions and sibling interactions on the emotional intelligence of school-aged children in urban poor areas.

\section{Methods}

Site selection in this research was done by purposive, that is, Empang Village, South Bogor Subdistrict and Tegal Lega Village, Bogor Tengah Sub-district, Bogor City, West Java. This is based on data from BPS that South Bogor and Central Bogor sub-districts have the number of Pre-KS and KS I according to the indicators of Population and Family Planning Agency (BKKBN) in most of the districts. The research was conducted from February to May 2016.

The population in this study was the family of Pre-KS and KS-I, which have children of school age 4-6 elementary school, live with biological mother, have siblings, and get government assistance in Bogor City area especially in Empang and Tegal Lega Urban Village, Central Bogor Subdistrict. The number of mother and child population in Empang urban village is 81 families while in Tegal Lega urban village is 149 families. Sample of this research is mother and child. Sampling is done by proportional random sampling based on the amount of data in Empang and Tegal Lega.

Types of data collected in this study included primary data and secondary data. Secondary data included general description and determination of research sites 
obtained from BPS, subdistrict and district data. Primary data were obtained through interviews to mothers and children using questionnaires relevant to the variables studied including child characteristics, family characteristics, parent and child interactions, sibling interaction, and emotional intelligence.

Parental-child interaction variables were measured using Parent-Child Relationship Inventory (PCRI) instrument developed by Gerard which was modified by the authors comprising 59 items of statements of a total of 78 statement items measured by Likert scale ie strongly disagree (score 1), not Agree (score 2), agree (score 3), strongly agree (score 4) with Cronbach's Alpha of 0.667. Sibling Relationship Questionaire variables from Furman and Buhrmester (1985) consisted of 55 questions using Likert scale consisting of never (score 1), rarely (score 2), often (score 3), very often (score 4) with Cronbach's Alpha of 0.895 . The emotional intelligence variable was measured using the emotional intelligence instrument developed by the researcher referring to Goleman's (2004) theory consisting of 40 questions with four Likert-scale answer choices similar to sibling interaction with Cronbach's Alpha of 0.798.

Categorization of parent-child interaction variables and sibling interactions used three cut-offs, less $(<60)$; enough $(60-80)$; and good $(>80)$. Emotional intelligence used three cut-offs, low $(<60)$; medium $(60-80)$; and high $(>80)$. The analysis used in this research was descriptive and inferential analysis. Descriptive analysis included the minimum and maximum values, mean, standard deviation, and frequency of child and family characteristics and variables studied. Inferential analysis included correlation test and multiple linear regression test to see the relationship and influence between variables.

\section{Characteristics of Child and Family}

\section{Results}

The results showed that the children in this study were male (52\%) and female $(48 \%)$ with the average age of children 10.50 years old and had the age range 9 to 13 years old. Child sample was a grade 4-6 students of Elementary school. Age categories and maternal age are divided into three, i.e. young adults, middle adults, and adulthood. Based on the results, more than half of the mother's age (57\%) was young adults (20-40 years) with an average of 39.93 years while 60 percent of fathers was middle-aged (4165 years). The average length of the mother's education was 7.41 years while the father's education was 7.94 years. More than two-thirds of the mother's employment $(89 \%)$ was unemployed or housewives. Half the example father has a job as a laborer. Based on research results, over half of the sample family (62\%) had income below the Bogor poverty line (Rp360 518). This proved that the example was a poor family in urban areas. Average family income was of Rp 351.599 with income ranging from Rp 60.000-Rp 875.000. Family sample (58\%) had large families with moderate family type with a range of 3-9 person family members.

\section{Parent-Child Interaction}

Based on the results of research more than some mothers have interaction with their child in enough category $(60 \%)$. Parent and child interaction was enough. This was marked by some mothers who still often have difficulty in disciplining children, often scold and threaten to hit children, allowing children when doing misbehavior, and some children who are often outside the home. School-age children already know the wider 
environment apart from the family environment, Such as school environments and peers. This is one cause of children who are often outside the home. Based on the result of achievements in each dimension, this indicated that the dimensions of parental support, satisfaction, communication, and autonomy are in the less category, while the dimensions of involvement, and the value orientation are in sufficient category.

Table 1 Distribution, mean, standard deviation, minimum, and maximum sample based on parent-child interaction

\begin{tabular}{lcc}
\hline Parent-child interaction & $\mathrm{n}$ & $\%$ \\
\hline Less $(<60)$ & 40 & 40,00 \\
Enough (60-80) & 60 & 60,00 \\
Good (>80) & 0 & 0,00 \\
\hline Total & 100 & \multicolumn{2}{c}{100,00} \\
Average \pm std & \multicolumn{2}{c}{$61,32 \pm 5,15$} \\
Min-max & \multicolumn{2}{c}{$46,89-74,58$} \\
\hline
\end{tabular}

\section{Interaction Siblings}

In addition to interacting with parents, children will interact with siblings, brother or sister. Based on the results of research, all dimensions of sibling interaction are in the category less. It is characterized by the interaction that is not optimal seen from the dimension of warmth and power is in the category less. The better interaction that exists is seen from the dimension of warmth and power, so the sibling's interaction will get better. The whole dimension of sibling interaction is in the low category. Most examples have a low interaction of 92 percent. This is marked by lack of interaction between siblings characterized by lack of good treatment. This never shares stories, nor does spend time together, humiliate and call by name, often quarrels, competes, disagrees and gets annoyed with each other.

Table 2 Distribution, mean, standard deviation, minimum, and maximum sample based on sibling interaction

\begin{tabular}{lcc}
\hline Sibling interaction & $\mathrm{n}$ & $\%$ \\
\hline Less $(<60)$ & 92 & 92,00 \\
Enough $(60-80)$ & 8 & 8,00 \\
Good $(>80)$ & 0 & 0,00 \\
\hline Total & 100 & 100,00 \\
Average \pm std & \multicolumn{2}{c}{$46,93 \pm 10,60$} \\
Min-max & \multicolumn{2}{c}{$17,57-79,39$} \\
\hline
\end{tabular}

\section{Emotional Intelligence}

The emotional intelligence of the child is the development of the child in terms of expressing the feeling of self with the right. Emotional intelligence of a person can be influenced by innate factors (natural) and environmental factors. Based on the results of previous research, this states that the success of a person as much as 80 percent is determined by emotional intelligence and 20 percent by intellectual acumen (Goleman, 2004). This proves that emotional intelligence is important. The results showed that half of respondents had achievement of emotional intelligence in the medium category $(55 \%)$. The child's emotional intelligence is in the moderate category marked by the 
child never telling a sad moment to his or her parents and never saying "I am angry" when angry and choosing silence to express his emotions.

According to Goleman (2004) emotional intelligence consists of self-awareness, self-regulation, motivation, empathy, and social skills. The dimension of setting is in the medium category of 64 percent and the social skills dimension $(50 \%)$ in the medium category. The other three dimensions are self-awareness, empathy, and motivation in the low category. Emotional intelligence of school-aged children in urban poor areas is in the moderate category due to several dimensions that have not been optimally achieved. It is marked that the child still has no motivation in him, such as, the child has not been able to control his own finances and have no sense of responsibility about cleanliness (washing dishes).

Table 3 Distribution, mean, standard deviation, minimum, and maximum sample based on emotional intelligence

\begin{tabular}{lcc}
\hline Emotional intelligence & $\mathrm{n}$ & $\%$ \\
\hline Low $(<60)$ & 45 & 45,00 \\
Medium (60-80) & 55 & 55,00 \\
High $(>80)$ & 0 & 0,00 \\
\hline Total & 100 & 100,00 \\
Average \pm std & \multicolumn{2}{c}{$58,58 \pm 9,13$} \\
Min-max & \multicolumn{2}{c}{$34,17-79,17$} \\
\hline
\end{tabular}

\section{Relationship of Child and Family Characteristics with Parent-Child Interaction and Interaction of Siblings}

Pearson correlation test results between child characteristics and family characteristics with parent-child interaction and sibling interaction showed that there was no significant relationship between child characteristics consisting of age with parent-child interaction and sibling interaction. Maternal age was negatively associated with parental and child interactions $(r=-0.211 ; \mathrm{p}<0.05)$. This means that the younger the age of the mother, the better the interaction will be. The younger mother tends to be closer to the child.

\section{Relationship between Child and Family Characteristics, Parent-Child Interaction, Sibling Interaction with Emotional Intelligence}

Pearson correlation test results showed that there is no significant relationship between the characteristics of children consisting of the age of children and emotional intelligence of children. Other results did not differ among family characteristics which showed no significant relationship with and emotional intelligence. The duration of maternal education was correlated significanlty positive with children's emotional intelligence $(r=0.262 ; p<0.01)$. This suggests that the higher the mother's education, the better the child's emotional intelligence. The results of this study proved a significant relationship between sibling's interaction and emotional intelligence $(r=$ $0,589, \mathrm{p}<0.01)$. This suggests that the better the interaction among siblings, the higher the emotional intelligence of the child. 
Table 4 Correlation coefficient between characteristic of child and family with parentchild interaction, sibling interaction, and emotional intelligence

\begin{tabular}{lc}
\hline Relationship between variables & emotional intelligence \\
\hline Age of child & $-0,122$ \\
Father's age & $-0,111$ \\
Father length of education & 0,083 \\
Mother's age & 0,023 \\
Mother length of education & $0,262^{* *}$ \\
Income per capita & 0,005 \\
Family size & $-0,128$ \\
Parent-child interaction & $-0,020$ \\
Sibling interaction & $0,589^{* *}$ \\
\hline Note: $*=$ significant $p<0.05 ; * *$ significant $p<0.01$ &
\end{tabular}

\section{Role of Child and Family Characteristics, Parent-Child Interaction, Siblings Interaction with Emotional Intelligence}

The results of multiple linear regression test in this study was conducted to find out how far the factors that affect the emotional intelligence of schoolchildren in urban poor areas. Table 5 shows the value of Adjusted R Square multiple linear regression test 0.360 , that is, as much as 36 percent of emotional intelligence is influenced by the variables used in testing this study, while as much as 64 percent is explained by other variables outside the variables studied. Factors influencing the emotional intelligence of school-aged children in urban poor areas in this study were the length of maternal education and sibling interactions.

Table 5 Influence of child and family characteristics, parent-child interaction, sibling interaction with emotional intelligence

\begin{tabular}{lccc}
\hline \multirow{2}{*}{ Variables } & \multicolumn{3}{c}{ Emotional intelligence } \\
\cline { 2 - 4 } & Unstandarized (B) & Standarized ( $\beta$ ) & Sig. \\
\hline Constan & 45,389 & & 0,003 \\
Age of child (year) & $-0,632$ & $-0,066$ & 0,421 \\
Father's age (year) & $-0,070$ & $-0,109$ & 0,294 \\
Father length of education (year) & 0,139 & 0,056 & 0,651 \\
Mother's age (year) & 0,020 & 0,015 & 0,881 \\
Mother length of education (year) & 0,670 & 0,200 & $0,043^{*}$ \\
& & & $*$ \\
Income per capita (rupiah) & $-4,729 \mathrm{E}-6$ & $-0,110$ & 0,212 \\
Family size (person) & $-0,359$ & $-0,054$ & 0,562 \\
Parent-child interaction (index score) & $-0,059$ & $-0,033$ & 0,690 \\
Sibling interaction (index score) & 0,488 & 0,566 & $0,000^{*}$ \\
& & & $* *$ \\
\hline F & & 7,190 & \\
Sig. & & 0,000 & \\
$\mathrm{R}^{2}$ & & 0,418 & \\
$\mathrm{R}^{2}$ Adjusted & & 0,360 & \\
\hline Note: $*^{* *}$ significant $p<0.05 ; * * *=$ significant $p<0.01$ & & &
\end{tabular}


Parental interactions have no significant effect on children's emotional intelligence. This is thought to be related to the interaction between parents' perceptions of the child and the parental interactions between children and the child's perception (two-way). Maternal education $(\mathrm{B}=0.670)$ has a significantly positive effect on children's emotional intelligence. That is, the longer the mother takes education, the higher the child's emotional intelligence by 0.670 points. Sibling interactions also have a significantly positive effect on the child's emotional intelligence $(B=0.488)$. This means that any increase in sibling interaction will raise emotional intelligence by 0.488 points.

\section{Discussion}

The results show that some of the students are scolding and threatening to hit children. Physical violence suffered by children can weaken emotional and behavior problems that can withstand adulthood and future social relationships, including the relationship between parent and child (Irzalinda, Puspitawati \& Muflikhati 2014). According to Mafriana (2003), parents who often experience stress conditions will cause the parents to become angry and beat his son. Then, a child raised by a family or parent who cannot develop a healthy functioning parent will be a trouble child in terms of child functioning, that is, children with growth problems such as arrogance, slow adaptation, and less intellectual intelligence. According to Elmanora, Muflikhati and Alfiasari (2012), parents who apply a nurturing style instead of emotional trainers or emotional neglect will allow the child to overcome his own emotions. This results in a child not learning to manage emotions well. Parenting and good interaction between parent and child will help the child's next development process.

The results also show that the interaction of siblings is in the category less. This is due to the warmth that exists among siblings is not so good and has a high level of conflict. The frequent conflicts among siblings are insulting each other, calling by name, quarreling, competing, and interfering with each other. The antagonisms of siblings are linked to low levels of parental acceptance and emotional closeness between parents and children (Alekseeva et al 2014). As Furman and Buhrmester (1985) point out in Kose and Demiriz (2009) the emotional bond between siblings in terms of strength lies second after the bond between parent and child.

Based on the results of the study, the emotional intelligence of school-aged children in urban poor areas is in the medium category. This research is in line with Punia and Sangwan (2011) which states that emotional intelligence in school-age children in urban areas is in the medium to high category. In addition, research Rachmawati (2015) also states that the emotional intelligence of school age children in rural areas is in the category of being.

Poverty experienced by parents tends to make parents unable to manage their emotions well, causing irritability. School-aged children in poor urban areas tend to express positive emotions such as happiness on holidays and doing homework compared to negative emotions such as telling sad stories parents. In addition, children also have a good empathy towards others.

The results showed that there was a significant negative relationship between maternal age and the interaction of mother and child. This shows that the younger the mother's age, the better the interaction between mother and child. This is because the age of the mother is in young adults on average has two children, so the closeness 
between mother and child is still well established. The interaction between parent and child can be seen from parenting, communication, relationships or bonding, and the quality of relationships. Hastuti et al. (2008) there is ample evidence that suggests poor relationships among mothers which cause the mother-child relationship to be worse in terms of communication, expression and emotional bonding.

The result of relationship test shows that the length of mother education is significantly positive with the emotional intelligence of child. Mother length of education also has a significantly positive effect on emotional intelligence. This means that the longer the mother takes education, the better the the emotional intelligence of children. This study is in line with Hastuti (2011), maternal education has a positive influence on the emotional development of school age children. In contrast to research conducted by Elmanora, Muflikhati, and Alfiasari (2012) that the duration of maternal education has no effect on the social development of children's emotions. Research results by Nandwana and Joshi (2010), parental education has a role in the development of children.

Sibling interactions have a significantly positive relationship with emotional intelligence. When a person has siblings, he/she will facilitate that person while interacting with others so that you can influence the behavior and developments for others. Several studies on sibling relationships have been widely practiced in European American families, and research on African American families in rural areas has also yielded similar results. When parents of African American families give positive things to their children, older siblings will develop better emotional control and care about their younger sibling (Brody et al, 1999). The interaction between parent and child with sibling interaction shows no significant relationship. This is not in line with the research of Furman and Buhrmester (1985), parent-child relationships have an effect on the child's interaction with siblings. According to Holilah (2013), authoritarian mothering will reduce the warmth of relationships in children with siblings. This proves that the interaction of parents and children will shape the child's interaction with his siblings. Interactions that occur will always be good when the child believes that parents will not be partial to one. The treatment given by the parents will be different in each child, thus causing jealousy among the siblings. The child's age has no relationship and influence with emotional intelligence. The higher the age of the child does not lead to increased emotional intelligence. Some studies say that age affects the development of children.

Result of influence test showed that sibling interaction has a significantly positive effect on emotional intelligence. This means that any increase in sibling interaction will have an effect on increasing the emotional intelligence of school age children. According to Howe et al. (2001) in Alkema (2013) says that high emotional competence is useful for relationships with siblings so as to understand emotions related to warmth in sibling relationships. The sibling relationship provides an important context for the development of children's understanding of social, emotional, moral, and cognitive factors (Howe \& Recchia, 2014, Howe et al, 2005, Volling et al., 2010) .Alkema (2013) states that the conflict relationship among siblings is related to the decreasing emotional competence.

Based on the ecological theory by Bronfenbrenner (1994), microsystem environment is the closest environment of the child that the child is to grow. The environment can affect one's development. One example of a home environment that can affect the child's development is the interaction that occurs in the family like parents 
Sons and siblings. This study does not show appropriate results, parent-child interaction has no effect on emotional intelligence. This is because children already know the wider environment. The interaction of siblings has an influence on emotional intelligence. This is consistent with the ecological theory that states that interactions occuring in a family can affect a child's development.

Limitations in this study were family interactions measured only on the interactions of children with mothers and the interaction of children with siblings. Family interactions also included the interaction of children with fathers, but this study was not used so that family interaction was not measured in its entirety. The limitation of further research is the absence of criteria related to sibling characteristics related to age and gender so as not to see the diversity of sibling interactions that occur.

\section{Conclusion}

\section{Conclusion and Suggestion}

The results showed that the emotional intelligence of school age children was in the medium category. This is characterized by a lack of motivation for children. Relationship test shows results that the longer the mother takes education, the better the child's emotional intelligence. The interaction of siblings warm will form a high emotional intelligence. Meanwhile, the results of the effect test indicate the mother's long education and interaction of siblings who are warm also consistently positively affect the emotional intelligence of school-aged children. This means that the longer the mother takes education and the siblings interaction warmly and well, the better the emotional intelligence of the child.

\section{Suggestion}

The study found that the duration of maternal education and sibling interaction had a major effect on the emotional intelligence of school-aged children. Therefore, it is recommended that mothers who have a higher education level or be given good parenting can attend training related to child emotions. A warm and good sibling interaction will have a major impact on the child's emotional intelligence. It is recommended that mothers teach children to have good interactions with their siblings. It is also recommended for further research to be able to see and analyze other factors that can affect children's emotional intelligence on child behavior in poor urban areas.

\section{Reference}

Aber J. L., Bennet N. G., Conley D. C., \& Jiali Li. (1997). The effects of poverty on child health and development. Annual Reviews Inc., 18, 463-483.

Alekseeva O. S., Kozlova I. E., Baskaeva O. V., \& Pyankova S. D. (2014). Intelligence and sibling relationship. Procedia Social and Behavior Sciences, 146(2014), 187191.doi: 10.1016/j.sbspro.2014.08.107

Alfiasari. (2007). Analisis ketahanan pangan rumah tangga miskin dan peranan modal sosial: Studi kasus pada rumah tangga miskin di Kecamatan Tanah Sereal dan Kecamatan Bogor Timur, Kota Bogor. [Tesis]. Bogor (ID): Institut Pertanian Bogor.

Ali M. M., \& Sarullah S. (2010). Typical Siblings' acceptance of siblings with special needs. Procedia Social and Behavioral Sciences, 9(2010), 517-521. doi:10.1016/j.sbspro.2010.12.190 
Alkema N. L. (2013). Associations between sibling relationship quality and emotional competence in middle childhood .[Thesis]. California (US): California State University.

[BPS] Badan Pusat Statistik (ID). 2015. Bogor dalam angka 2015.

Brody, G. H., Flor, D., \& Gibson, N. M. (1999). Linking maternal efficacy beliefs, developmental goals, parenting practices, and child competence in rural singleparent African American families. Child Development, 70, 1197-1208. Bronfenbrenner U. (1994). Ecological models of human development. International Encyclopedia of Education, 3(2),37-43.

Eamon M. K. (2001). The effects of poverty on children's socioemotional development: an ecological system analysis. Social Work, 46(3), 256-266.

Elmanora., Muflikhati I., \&Alfiasari. (2012). Gaya pengasuhan dan perkembangan sosial emosi anak usia sekolah pada keluarga petani kayu manis. Jur. Ilm. Kel. Kons, 5(2), 128-137.

Engle P. L., \& Black M. M. The Effect of Poverty on Child Development and Educational Outcomes.

Evans G. W. (2004). The environment of childhood poverty.American Psychologist, 59(2), 77-92.

Furman W., \& Buhrmester D. (1985). Children's perception of the qualities of sibling relationships. J Child Dec, 56, 448-461.

Goleman D. (2004). Emotional Intelligence Kecerdasan Emosional Mengapa EI Lebih Penting daripada IQ. T Hermaya, Penerjemah. Jakarta: Gramedia Pustaka Utama. Terjemahan dari Emotional Intelligence.

Gottman J., \& DeClaire J. (1997). The Heart of Parenting. British: Bloomsbury Publishing.

Hastuti D., Syarief H., Megawangi R., Guhardja S., \& Patmonodewo S. (2008). Karakteristik keluarga, interaksi ibu-anak dan pengasuhan serta pengaruhnya pada tumbuh kembang anak di Bogor dan Depok. Media Gizi \& Keluarga, 32(1), 4255.

Hastuti R. (2011). Analisis nilai anak, kualitas pengasuhan, dan perkembangan anak usia sekolah pada keluarga petani karet dan petani sawit di Kabupaten Bungo (Skripsi), Institut Pertanian Bogor, Bogor.

Hoeve M., Dubas J. S., Eichelsheim V. I., Van der Laan P. T., Smeek W., \& Gerris J. R. M. (2009). The relationship between parenting and delinquency: a meta-analysis. J Abnorm Child Psychol 37, 749-775. doi:10.1007/s10802-009-9310-8

Holilah S. (2013). Gaya pengasuhan ibu dan interaksi saudara kandung pada remaja berdasarkan status pekerjaan ibu (Skripsi), Institut Pertanian Bogor, Bogor.

Howe N., \& Recchia H. (2014). Sibling relations and their impact on children's development. Encyclopedia on Early Childhood Development.

Irzalinda V., Puspitawati H., \& Muflikhati I. (2014). Aktivitas bersama orang tua-anak dan perlindungan anak meningkatkan kesejahteraan subjektif anak. Jur.Ilm. Kel. \& Kons, 7(1), 40-47.

King D. L. (2007). How non-disabled children respond to a sibling with disability? : the challenges they may or may not haved faced [Thesis]. Northampton, Massachusetts: Smith College School for Social Work. 
Kose F., \& Demiriz S. (2009). An affair analysis of mother's attitudes and 9 years old offspring' sibling relations. Procedia - Social and Behavioral Sciences, 1(2009), 872-876.doi:10.1016/j.sbspro.2009.01.15

Mafriana S. B. (2003). Fungsi ekspresif-instrumental orang tua dan kecerdasan emosional anak: studi komparatif lintas budaya antara Etnik Banjar dan Etnik Madura. [Tesis]. Bogor (ID): Institut Pertanian Bogor.

Nandwana S., \& Joshi K. (2010). Assessment of emotional intelligence of tribal adolescents of Udaipur: an explonatory study. Stud Tribes Tribals, 8(1), 37-40.

Punia, S., \& Sangwan, S. (2011). Emotional Intelligence and Social Adaptation of School Children. Journal Psychology, 2(2): 83-87 (2011)

Rachmawati M. (2015). Pengaruh sosialisasi emosi dan kecerdasan emosi terhadap perilaku agresi anak usia sekolah pada keluarga perdesaan (Skripsi), Institut Pertanian Bogor, Bogor.

Setyowati Y. (2005). Pola komunikasi keluarga dan perkembangan emosi anak (studi kasus penerapan pola komunikasi keluarga dan pengaruhnya terhadap perkembangan emosi anak pada keluarga Jawa). Jurnal Ilmu Komunikasi, 2(1), $67-78$. 